\title{
Expected Effects on Protein Yield of Marker-Assisted Selection at Quantitative Trait Loci Affecting Milk Yield and Milk Protein Percentage
}

\author{
E. Lipkin, ${ }^{* 1}$ A. Bagnato, $†$ and M. Soller* \\ *Department of Genetics, Alexander Silberman Institute of Life Science, Hebrew University of Jerusalem, Jerusalem 91904, Israel \\ †Department of Veterinary Sciences and Technologies for Food Safety, Università degli Studi di Milano, 20133 Milano, Italy
}

\begin{abstract}
Protein yield (PY) is currently the major economic product of the dairy herd. Genome-wide scans for quantitative trait loci (QTL) affecting milk yield (MY) and milk protein percentage $(\mathrm{PP})$ suggest that of the loci affecting the 2 traits, about $1 / 4$ exclusively affect MY, $1 / 4$ exclusively affect $\mathrm{PP}$, and half affect both traits. Because PY is the product of MY and PP, it is of interest to evaluate the expected effects on PY of marker-assisted selection (MAS) applied to these 3 classes of QTL. It is clear that selection for the appropriate allele at QTL exclusively affecting MY or PP will have a positive effect on PY. The question arises as to the effect of MAS directed at QTL affecting both MY and PP. Because the observed genetic correlation of about -0.5 between MY and PP must be generated by these loci, and because they comprise about half the total number of loci affecting the 2 traits, it can be inferred that the genetic correlation between MY and PP at loci affecting both traits is close to -1.0. This seems to imply that generally such loci would be neutral in their effects on PY. In the present study, biometrical expressions originally developed to describe the relationships of MY, fat percentage, and fat yield were adapted to describe the relationships of MY, PP, and PY. The resultant expressions were validated by showing that they correctly predicted the observed phenotypic standard deviation and heritability of PY, and the vastly different genetic correlations of PY with MY (very high positive) and of PY with PP (very low positive). Contrary to initial impressions, further biometrical analysis of the projected effects on PY of MAS at the loci affecting both traits, showed that even under the assumption that the genetic correlation between MY and PP at these loci is -1.0, selection for the allele favoring MY will have a strong positive effect on PY, whereas selection for the allele favoring PP will
\end{abstract}

Received January 10, 2008.

Accepted March 19, 2008.

${ }^{1}$ Corresponding author: lipkin@vms.huji.ac.il have an equal but opposite negative effect on PY. These diametrically opposed effects are due to the lower genetic coefficient variation of PP compared with MY. It is speculated that the reduced coefficient of variation of PP may be because of more stringent homeostatic buffering of milk composition compared with milk yield. Key words: quantitative trait locus, marker-assisted selection, productive trait, expected genetic gain

\section{INTRODUCTION}

At the present time, protein is the main economic output of the dairy herd, and a large fraction of the overall selection effort is devoted to increasing protein yield (PY). Recently, 3 genome scans for QTL affecting milk yield (MY) and milk protein percentage (PP) (Bagnato et al., 2008a; Chamberlain et al., 2008; Lipkin et al., 2008) showed, even after correcting for incomplete power, that there are 3 classes of QTL with respect to effects on these 2 traits: 1 ) those that exclusively affect PP with little effect on MY; 2) those that exclusively affect MY with little effect on PP; and 3) those that affect both traits. Bagnato et al. (2008a) dealt with the problem of incomplete power by comparing specificity of QTL effects in Brown Swiss and Holstein. Lipkin et al. (2008) and Chamberlain et al. (2008) used reverse statistical approaches: Lipkin et al. (2008) used a relatively low type I error, but corrected for high type II error, whereas Chamberlain et al. (2008) used a low type II error, but corrected for high type I error. Because the genetic covariance between PP and MY is zero for loci affecting PP or MY exclusively, the observed genetic correlation between PP and MY must be generated by those QTL affecting both MY and PP. Two of the studies cited above (Bagnato et al., 2008a; Lipkin et al., 2008) found that about half of QTL affecting MY or PP affect exclusively only one of these traits, and half affect both traits. Many studies (reviewed in Table 1) showed that the genetic correlation of MY and PP averaged -0.49 . These studies include the estimates of the genetic correlation between MY and PP for the populations on which the 2 genome scans cited above were based, namely, 
Table 1. Literature reports of heritability and genetic correlations between protein percentage (PP), protein yield (PY), and milk yield (MY) in dairy cattle

\begin{tabular}{|c|c|c|c|c|c|c|}
\hline \multirow[b]{2}{*}{ Study } & \multicolumn{3}{|c|}{ Heritability } & \multicolumn{3}{|c|}{ Genetic correlations } \\
\hline & $\mathrm{PP}$ & PY & MY & PP-PY & PP-MY & MY-PY \\
\hline $\begin{array}{l}\text { Review of } 11 \text { studies } \\
\text { (Chauhan and Hayes, 1991) }\end{array}$ & 0.5 & 0.3 & 0.3 & $\begin{array}{l}0.06 \\
(-0.16 \text { to } 0.37)\end{array}$ & $\begin{array}{l}-0.48 \\
(-0.21 \text { to }-0.64)\end{array}$ & $\begin{array}{l}0.84 \\
(0.77 \text { to } 0.91)\end{array}$ \\
\hline Chauhan and Hayes (1991) & 0.6 & 0.3 & 0.3 & 0.08 & -0.54 & 0.79 \\
\hline Welper and Freeman (1992) & 0.5 & 0.3 & 0.3 & -0.12 & -0.47 & 0.93 \\
\hline Schutz et al. (1990) & 0.58 & 0.14 & 0.16 & 0.36 & -0.58 & 0.51 \\
\hline Castillo-Juarez et al. (2002) & 0.56 & 0.26 & 0.28 & 0.10 & -0.43 & 0.92 \\
\hline Sölkner (1989) & 0.48 & 0.25 & 0.29 & 0.053 & -0.46 & 0.86 \\
\hline Ron et al. (2004) & & & & 0.09 & -0.65 & 0.70 \\
\hline Lipkin et al. (2008) & & & & 0.17 & -0.50 & 0.77 \\
\hline Santus et al. (1993) & 0.42 & 0.3 & 0.32 & 0.03 & -0.36 & 0.92 \\
\hline Bagnato et al. (2008b) & 0.41 & 0.18 & 0.22 & -0.01 & -0.45 & 0.90 \\
\hline Mean (above studies) & 0.51 & 0.25 & 0.27 & 0.08 & -0.49 & 0.81 \\
\hline
\end{tabular}

Israel Holstein (-0.50; Lipkin et al., 2008) and Italian Brown Swiss (-0.45; Bagnato et al., 2008b). Taking these parameter values as representative, the genetic correlation of MY and PP for loci affecting both traits would be about -1.0. That is, loci simultaneously affecting both traits affect them genetically in equal and opposite directions. On this assumption, and taking into account that $\mathrm{PY}=\mathrm{MY} \times \mathrm{PP}$, we speculated that loci simultaneously affecting both MY and PP would be neutral with respect to their effect on PY (Bagnato et al., 2008a; Lipkin et al., 2008).

Thirty years ago, Essl (1978) explored in detail the underlying biometrical relationships among MY, fat yield, and fat percentage. The same relationships clearly hold for MY, PP, and PY. Although Essl (1978) did not consider the effects on fat yield of selection for MY and fat percentage, they can be obtained readily from his expressions. In the present paper, the application of the expressions developed by Essl (1978) to MY, $\mathrm{PP}$, and PY is validated by showing that these expressions explain the observed values obtained for the phenotypic standard deviation and heritability of PY, and for the genetic correlations of MY and PY, and of PP and PY (summarized in Table 1). The results of Essl (1978) are here extended to evaluate the impact of the effects on PY of phenotype-based selection such as BLUP-EBV for PP or MY and for marker-assisted selection (MAS) specifically directed to each of the above 3 classes of QTL. An expression similar to that presented by Essl (1978) was derived independently by Visscher and Thompson (1992), and although not developed to the same degree as in the Essl (1978) study, could equally have served as a basis for the present analysis.

\section{MATERIALS AND METHODS}

\section{Biometrical Relationships Among PP, MY, and PY (Following Essl, 1978)}

Let $\mu_{\mathrm{PP}}$ and $\mu_{\mathrm{MY}}=$ the population means of $\mathrm{PP}$ and $\mathrm{MY}$, respectively; $\sigma_{\mathrm{PP}}^{2}$ and $\sigma_{\mathrm{MY}}^{2}=$ the population pheno- typic variance of $\mathrm{PP}$ and $\mathrm{MY}$, respectively; $\mathrm{h}_{\mathrm{PP}}^{2}$ and $\mathrm{h}_{\mathrm{MY}}^{2}=$ the heritabilities of $\mathrm{PP}$ and MY, respectively; $\sigma_{\mathrm{APP}}^{2}$ and $\sigma_{\mathrm{AMY}}^{2}=$ the population additive genetic variance of $\mathrm{PP}$ and MY (i.e., $\mathrm{h}_{\mathrm{PP}}^{2} \sigma_{\mathrm{PP}}^{2}$ and $\mathrm{h}_{\mathrm{MY}}^{2} \sigma_{\mathrm{MY}}^{2}$, respectively); $\mathrm{r}_{\mathrm{P}(\mathrm{PP}, \mathrm{MY})}$ and $\mathrm{r}_{\mathrm{A}(\mathrm{PP}, \mathrm{MY})}=$ the phenotypic and genetic correlations between $\mathrm{PP}$ and $\mathrm{MY}$, respectively; and $\sigma_{\mathrm{P}(\mathrm{PP}, \mathrm{MY})}$ and $\sigma_{\mathrm{A}(\mathrm{PP}, \mathrm{MY})}=$ phenotypic and genetic covariance of $\mathrm{PP}$ and $\mathrm{MY}$, calculated as $\mathrm{r}_{\mathrm{P}(\mathrm{PP}, \mathrm{MY})} \sigma_{\mathrm{PP}} \sigma_{\mathrm{MY}}$ and $\mathrm{r}_{\mathrm{A}(\mathrm{PP}, \mathrm{MY})} \sigma_{\mathrm{APP}} \sigma_{\mathrm{AMY}}$, respectively. Then, based on Essl (1978), we can write the following expressions for the heritability of $\mathrm{PY}\left(\mathrm{h}_{\mathrm{PY}}^{2}\right)$, and for the genetic correlations between $\mathrm{PP}$ and $\mathrm{PY}\left[\mathrm{r}_{\mathrm{A}(\mathrm{PP}, \mathrm{PY})}\right]$ and between $\mathrm{MY}$ and $P Y\left[r_{A(M Y, P Y}\right)$ :

$$
\begin{gathered}
\mathrm{h}_{\mathrm{PY}}^{2}=\sigma_{\mathrm{APY}}^{2} / \sigma_{\mathrm{PY}}^{2}, \\
\mathrm{r}_{\mathrm{A}(\mathrm{PP}, \mathrm{PY})}=\left(\mu_{\mathrm{PP}} \sigma_{\mathrm{A}(\mathrm{PP}, \mathrm{MY})}+\mu_{\mathrm{MY}}^{2} \sigma_{\mathrm{APP}}^{2}\right) / \sigma_{\mathrm{APP}} \sigma_{\mathrm{APY}}, \\
\mathrm{r}_{\mathrm{A}(\mathrm{MY}, \mathrm{PY})}=\left(\mu_{\mathrm{MY}} \sigma_{\mathrm{A}(\mathrm{PP}, \mathrm{MY})}+\mu_{\mathrm{PP}} \sigma_{\mathrm{AMY}}^{2}\right) / \sigma_{\mathrm{AMY}} \sigma_{\mathrm{APY}},
\end{gathered}
$$

where, assuming normal distribution of PP and MY (Essl, 1978), $\sigma_{\mathrm{APY}}^{2}=$ additive genetic variance of PY; which equals $\mu_{\mathrm{PP}}^{2} \sigma_{\mathrm{AMY}}^{2}+\mu_{\mathrm{MY}}^{2} \sigma_{\mathrm{APP}}^{2}+\sigma_{\mathrm{APP}}^{2} \sigma_{\mathrm{AMY}}^{2}+$ $\sigma_{\mathrm{A}(\mathrm{PP}, \mathrm{MY})}^{2}+2 \mu_{\mathrm{PP}} \mu_{\mathrm{MY}} \sigma_{\mathrm{A}(\mathrm{PP}, \mathrm{MY})} ; \sigma_{\mathrm{PY}}^{2}=$ phenotypic variance of PY, which equals $\mu_{\mathrm{PP}}^{2} \sigma_{\mathrm{MY}}^{2}+\mu_{\mathrm{MY}}^{2} \sigma_{\mathrm{PP}}^{2}+\sigma_{\mathrm{PP}}^{2} \sigma_{\mathrm{MY}}^{2}+$ $\sigma_{\mathrm{P}(\mathrm{PP}, \mathrm{MY})}^{2}+2 \mu_{\mathrm{PP}} \mu_{\mathrm{MY}} \sigma_{(\mathrm{PP}, \mathrm{MY})}$. Because PY is the product of PP and MY, the effect of an increase in PP on PY depends on the mean value of MY and vice versa. For example, an increase in PP of $0.10 \%$ (i.e., $0.001 \mathrm{~g} / \mathrm{mL}$ ) will contribute an additional $10 \mathrm{~kg}$ to PY if mean milk yield is $10,000 \mathrm{~kg} / \mathrm{yr}$, but only $5 \mathrm{~kg}$ if mean milk yield is $5,000 \mathrm{~kg} / \mathrm{yr}$; conversely, an increase of $1,000 \mathrm{~kg} / \mathrm{yr}$ in milk will contribute $40 \mathrm{~kg} / \mathrm{yr}$ to $\mathrm{PY}$ if mean PP is $4 \%$ $(0.04 \mathrm{~g} / \mathrm{mL})$, but only $30 \mathrm{~kg} / \mathrm{yr}$ if mean PP is $3.0 \%$. Consequently, the mean values of MY and PY enter into the above expressions with nontrivial effect. In particular, because $\mu_{\mathrm{MY}} \sigma_{\mathrm{APP}}^{2}$ is ordinarily much smaller than 
$\mu_{\mathrm{PP}} \sigma_{\mathrm{AMY}}^{2}$, it follows that $\mathrm{r}_{\mathrm{A}(\mathrm{PP}, \mathrm{PY})}$, the genetic correlation between $\mathrm{PP}$ and $\mathrm{PY}$, is always much less than $\mathrm{r}_{\mathrm{A}(\mathrm{MY}, \mathrm{PY}) \text {, }}$ the genetic correlation of MY and PY. This has obvious implications for the effects on PY of selection for PP or MY.

Five of the studies summarized in Table 1 (Sölkner, 1989; Schutz et al., 1990; Santus et al., 1993; CastilloJuarez et al., 2002; Bagnato et al., 2008b) include values for population means, phenotypic standard deviations, heritabilities, and phenotypic and genetic correlations of MY, PP, and PY. To validate the biometrical expressions presented above, the parameter values for MY and $\mathrm{PP}$ were substituted in the expressions for the phenotypic standard deviation and heritability of PY and its genetic correlations with MY and PP and the resultant parameter estimates were compared with those obtained by direct analysis of the data.

\section{Effects on PY of Phenotype-Based Selection and MAS for PP and MY}

To reduce the evaluation of phenotype-based selection and MAS to its essentials (i.e., to that obtained under equivalent heritability, selection intensity, and generation interval), we considered the effect on PY of an increase of 1 genetic standard deviation of trait value in each of the 2 traits MY and PP, if achieved by phenotype-based selection (which is necessarily directed at all classes of loci affecting both PP and MY or exclusively one of them), or by MAS directed specifically to loci affecting exclusively PP, exclusively MY, or affecting both traits.

Effects of Phenotype-Based Selection. The net effect on PY of phenotype-based selection for either of its 2 factors, PP or MY, will have 2 components. The first due to the effect on PY of the selection for a given trait (PP or MY, as the case might be), and the second due to the effect on PY that results from the correlated genetic effect of the selection for the selected trait on the "correlated trait" (MY or PP, as the case might be). That is, an increase in MY will not only result in an increase in PY (depending on the mean PP), but will also be followed by a decrease in PP as a result of the negative correlation between MY and PP. This in turn, will reduce some of the direct increase of PY. These relationships are summarized in the following expressions, which give the net effect on PY of a final state genetic change of 1 genetic standard deviation in MY or PP, namely,

$$
\begin{aligned}
& \Delta \mathrm{PY}\left(\sigma_{\mathrm{AMY}}\right)=\sigma_{\mathrm{AMY}} \mu_{\mathrm{PP}}+\mathrm{r}_{\mathrm{A}(\mathrm{MY}, \mathrm{PP})} \sigma_{\mathrm{APP}} \mu_{\mathrm{MY}}, \\
& \Delta \mathrm{PY}\left(\sigma_{\mathrm{APP}}\right)=\sigma_{\mathrm{APP}} \mu_{\mathrm{MY}}+\mathrm{r}_{\mathrm{A}(\mathrm{MY}, \mathrm{PP})} \sigma_{\mathrm{AMY}} \mu_{\mathrm{PP}},
\end{aligned}
$$

where $\Delta \mathrm{PY}\left(\sigma_{\mathrm{AMY}}\right)$ and $\Delta \mathrm{PY}\left(\sigma_{\mathrm{APP}}\right)$ are the net genetic gains in PY resulting from an increase of 1 genetic standard deviation $\left(\sigma_{\mathrm{A}}\right)$ in $\mathrm{MY}$ or $\mathrm{PP}$, respectively; and $\sigma_{\mathrm{AMY}} \mu_{\mathrm{PP}}$ and $\sigma_{\mathrm{APP}} \mu_{\mathrm{MY}}$ are the direct genetic effects on PY due to an increase of $1 \sigma_{\mathrm{A}}$ in the selected trait, MY or PP, respectively. As noted, these depend not only on the increase in MY or PP, but also on the mean population values for MY and PP. Finally, $r_{\mathrm{A}(\mathrm{MY}, \mathrm{PP})} \sigma_{\mathrm{APP}} \mu_{\mathrm{MY}}$ and $r_{\mathrm{A}(\mathrm{MY}, \mathrm{PP})} \sigma_{\mathrm{AMY}} \mu_{\mathrm{PP}}$ are the genetic effects on PY due to effects on the correlated trait, PP or MY, respectively, of the selection on the selected trait.

Because of the critical importance of the quantities $\sigma_{\mathrm{AMY}} \mu_{\mathrm{PP}}$ and $\sigma_{\mathrm{APP}} \mu_{\mathrm{MY}}$ in expressions [1] and [2], it is important to reformulate these expressions in terms of their ratio:

$$
\begin{gathered}
\mathrm{k}=\sigma_{\mathrm{AMY}} \mu_{\mathrm{PP}} / \sigma_{\mathrm{APP}} \mu_{\mathrm{MY}}=\left(\sigma_{\mathrm{AMY}} / \mu_{\mathrm{MY}}\right) /\left(\sigma_{\mathrm{APP}} / \mu_{\mathrm{PP}}\right)= \\
\mathrm{CV}_{\mathrm{MY}} / \mathrm{CV}_{\mathrm{PP}},
\end{gathered}
$$

where $\mathrm{CV}_{\mathrm{MY}}$ and $\mathrm{CV}_{\mathrm{PP}}$ are the genetic coefficients of variation of $\mathrm{MY}$ and $\mathrm{PP}$, respectively.

When expressed in terms of $k$, the following expression is obtained for proportional gain, $\mathrm{PG}_{(\mathrm{PP} / \mathrm{MY})}$, due to selection on PP compared with selection on MY

$$
\begin{gathered}
\mathrm{PG}_{(\mathrm{PP} / \mathrm{MY})}=\Delta \mathrm{PY}\left(\sigma_{\mathrm{APP}}\right) / \Delta \mathrm{PY}\left(\sigma_{\mathrm{AMY}}\right)= \\
\left(1+\mathrm{kr}_{\mathrm{A}(\mathrm{MY}, \mathrm{PP})}\right) /\left(\mathrm{k}+\mathrm{r}_{\mathrm{A}(\mathrm{MY}, \mathrm{PP})}\right) .
\end{gathered}
$$

Examination of equation [3] shows that as $\mathrm{k}$ increases, $\mathrm{PG}_{(\mathrm{PP} / \mathrm{MY})}$ decreases. Thus, the relative effect of phenotype-based selection for PP (compared with MY) depends on $\mathrm{k}$.

Effects of MAS. For selection on QTL affecting exclusively PP or exclusively MY, only the direct effects on PY are obtained; effects through the correlated trait are not present. Thus,

$$
\begin{aligned}
& \Delta \mathrm{PY}(\mathrm{MAS})\left(\sigma_{\mathrm{AMY}}\right)=\sigma_{\mathrm{AMY}} \mu_{\mathrm{PP}}, \\
& \Delta \mathrm{PY}(\mathrm{MAS})\left(\sigma_{\mathrm{APP}}\right)=\sigma_{\mathrm{APP}} \mu_{\mathrm{MY}}
\end{aligned}
$$

and

$$
\mathrm{PG}_{(\mathrm{MAS})(\mathrm{PP} / \mathrm{MY})}=1 / \mathrm{k} \text {. }
$$

The effect of selection on QTL that affect both PP and MY will depend on whether selection is for the allele with positive effect on MY or for the allele with positive effect on PP. In these cases, equations [1] and [2] apply, except that the genetic correlation between $\mathrm{PP}$ and MY for these loci, denoted $\mathrm{r}_{\mathrm{A}(\mathrm{MY}, \mathrm{PP})}{ }^{\prime}$, will be different than the overall genetic correlation between $\mathrm{PP}$ and MY: 
Table 2. Literature estimates of biometrical parameters used for calculation of heritability of protein yield (PY) and its genetic correlations with protein percentage $(\mathrm{PP}, \mathrm{g} / \mathrm{mL})$ and milk yield $(\mathrm{MY}, \mathrm{kg} / \mathrm{yr})$

\begin{tabular}{|c|c|c|c|c|c|c|c|c|c|}
\hline \multirow[b]{2}{*}{ Study } & \multirow[b]{2}{*}{ Trait } & \multicolumn{8}{|c|}{ Parameter $^{1}$} \\
\hline & & Mean & $\mathrm{SD}$ & $\mathrm{h}^{2}$ & $\sigma_{\mathrm{A}}$ & $\mathrm{r}_{\mathrm{A}(\mathrm{MY}, \mathrm{PP})}$ & $\sigma_{\mathrm{A}(\mathrm{MY}, \mathrm{PP})}$ & $\mathrm{r}_{\mathrm{P}(\mathrm{MY}, \mathrm{PP})}$ & $\sigma_{\mathrm{P}(\mathrm{MY}, \mathrm{PP})}$ \\
\hline Castillo-Juarez et al. (2002) & $\begin{array}{l}\text { MY } \\
\text { PP }\end{array}$ & $\begin{array}{l}9,916 \\
0.0326\end{array}$ & $\begin{array}{l}1,944 \\
0.0022\end{array}$ & $\begin{array}{l}0.28 \\
0.56\end{array}$ & $\begin{array}{l}1,028 \\
0.0016\end{array}$ & -0.43 & -0.70 & -0.31 & -1.326 \\
\hline Schutz et al. (1990) & $\begin{array}{l}\text { MY } \\
\text { PP }\end{array}$ & $\begin{array}{r}6,477 \\
0.0319\end{array}$ & $\begin{array}{r}1,162 \\
0.0022\end{array}$ & $\begin{array}{l}0.20 \\
0.62\end{array}$ & $\begin{array}{l}520 \\
0.0017\end{array}$ & -0.58 & -0.48 & -0.44 & -1.125 \\
\hline Sölkner (1989) & $\begin{array}{l}\text { MY } \\
\text { PP }\end{array}$ & $\begin{array}{l}3,926 \\
0.0326\end{array}$ & $\begin{array}{l}578 \\
0.0018\end{array}$ & $\begin{array}{l}0.31 \\
0.52\end{array}$ & $\begin{array}{l}322 \\
0.0013\end{array}$ & -0.46 & -0.19 & -0.31 & -0.323 \\
\hline Bagnato et al. (2008b) & $\begin{array}{l}\text { MY } \\
\text { PP }\end{array}$ & $\begin{array}{l}5,894 \\
0.0348\end{array}$ & $\begin{array}{l}915 \\
0.0019\end{array}$ & $\begin{array}{l}0.22 \\
0.41\end{array}$ & $\begin{array}{l}432 \\
0.0012\end{array}$ & -0.45 & -0.23 & -0.22 & -0.374 \\
\hline Mean & $\begin{array}{l}\text { MY } \\
\text { PP }\end{array}$ & $\begin{array}{r}6,517 \\
0.033\end{array}$ & $\begin{array}{r}1,101 \\
0.002\end{array}$ & $\begin{array}{l}0.27 \\
0.51\end{array}$ & $\begin{array}{l}564 \\
0.001\end{array}$ & -0.46 & -0.36 & -0.30 & -0.701 \\
\hline
\end{tabular}

${ }^{1}$ Mean = population mean; $\mathrm{SD}=$ phenotypic standard deviation; $\mathrm{h}^{2}=$ heritability; $\sigma_{\mathrm{A}}=$ additive genetic $\mathrm{SD} ; \mathrm{r}_{\mathrm{A}(\mathrm{MY} \mathrm{PP})}=$ genetic correlation of MY and PP; $\sigma_{\mathrm{A}(\mathrm{MY}, \mathrm{PP})}=$ genetic covariance of $\mathrm{MY}$ and $\mathrm{PP} ; \mathrm{r}_{\mathrm{P}(\mathrm{MY}, \mathrm{PP})}=$ phenotypic correlation of $\mathrm{MY}$ and $\mathrm{PP} ; \sigma_{\mathrm{P}(\mathrm{MY}, \mathrm{PP})}=$ phenotypic covariance of MY and PP.

$$
\begin{aligned}
& \Delta \mathrm{PY}(\mathrm{MAS} \text { on } \mathrm{MY})=\sigma_{\mathrm{AMY}} \mu_{\mathrm{PP}} \\
& +\mathrm{r}_{\mathrm{A}(\mathrm{MY}, \mathrm{PP})^{\prime}} \sigma_{\mathrm{APP}} \mu_{\mathrm{MY}}, \\
& \Delta \mathrm{PY}(\mathrm{MAS} \text { on } \mathrm{PP})=\sigma_{\mathrm{APP}} \mu_{\mathrm{MY}} \\
& +\mathrm{r}_{\mathrm{A}(\mathrm{MY}, \mathrm{PP})^{\prime}} \sigma_{\mathrm{AMY}} \mu_{\mathrm{PP}} .
\end{aligned}
$$

Because the genetic covariance between $\mathrm{PP}$ and $\mathrm{MY}$ must be zero for loci affecting PP or MY exclusively, the observed genetic correlation between PP and MY must be generated by those QTL affecting both MY and $\mathrm{PP}$. Thus, $\mathrm{r}_{\mathrm{A}(\mathrm{MY}, \mathrm{PP})^{\prime}}=\mathrm{r}_{\mathrm{A}(\mathrm{MY}, \mathrm{PP})} / \mathrm{Q}_{\mathrm{MY}, \mathrm{PP}}$, where $\mathrm{Q}_{\mathrm{MY}, \mathrm{PP}}$ is the proportion of QTL affecting both traits. As noted previously, Bagnato et al. (2008a) and Lipkin et al. (2008) found that about half of QTL affecting MY or $\mathrm{PP}$ affected exclusively only one of these traits, and half affected both traits, so that $\mathrm{Q}_{\mathrm{MY}, \mathrm{PP}}=0.5$. Many studies (reviewed in Table 1 ) show that $\mathrm{r}_{\mathrm{A}(\mathrm{MY}, \mathrm{PP})} \approx-0.50$. On the assumption that these parameter values are representative, we have $\mathrm{r}_{\mathrm{A}(\mathrm{MY}, \mathrm{PP})^{\prime}}=-1.0$. That is, selection for alleles at these loci that increase MY by 1 genetic standard deviation of MY will decrease $\mathrm{PP}$ by an equivalent amount (i.e., 1 genetic standard deviation of PP); selection for alleles that increase PP by $\sigma_{\mathrm{APP}}$ will decrease MY by $\sigma_{\mathrm{AMY}}$. Although these effects appear to be symmetrical, selection at these loci will not be neutral in its effects on PY. Because (as noted above) $\sigma_{\mathrm{APP}} \mathbf{M}_{\mathrm{MY}}$ is much smaller than $\sigma_{\mathrm{AMY}} \mathrm{M}_{\mathrm{PP}}$, selection for the alleles at these loci that increase MY will increase PY, whereas selection for the alleles that increase PP will decrease PY.

\section{RESULTS}

Table 2 shows the values of the various biometrical parameters for MY and PP needed to calculate $\sigma_{\mathrm{PY}}$,
$\mathrm{h}_{\mathrm{PY}}^{2}, \mathrm{r}_{\mathrm{A}(\mathrm{PP}, \mathrm{PY})}$, and $\mathrm{r}_{\mathrm{A}(\mathrm{MY}, \mathrm{PY})}$ from the biometrical expressions given above, as provided from 5 published studies. Values for mean, $\mathrm{SD}, \mathrm{h}_{\mathrm{PP}}^{2}, \mathrm{~h}_{\mathrm{MY}}^{2}, \mathrm{r}_{\mathrm{A}(\mathrm{MY}, \mathrm{PP})}$, and $\mathrm{r}_{\mathrm{P}(\mathrm{MY}, \mathrm{PP})}$ were obtained directly from the studies; values for $\sigma_{\mathrm{A}}$, $\sigma_{\mathrm{A}(\mathrm{MY}, \mathrm{PP})}$, and $\sigma_{\mathrm{P}(\mathrm{MY}, \mathrm{PP})}$ were calculated from these values using the equations given in Materials and Methods. Table 3 shows the estimated values (as calculated in this study) for $\sigma_{\mathrm{PY}}, \mathrm{h}_{\mathrm{PY}}^{2}, \mathrm{r}_{\mathrm{A}(\mathrm{PP}, \mathrm{PY})}$, and $\mathrm{r}_{\mathrm{A}(\mathrm{MY}, \mathrm{PY})}$ obtained on the basis of these parameters, compared with observed values reported in these studies as obtained by direct calculation. The correspondence of estimated and observed parameters was generally very close for all 4 estimated parameters. Thus, the expressions developed by Essl (1978) account fully for the phenotypic standard deviation and heritability of PY, and account well for the very low genetic correlation between $\mathrm{PP}$ and $\mathrm{PY}$ on the one hand, and the very high genetic correlation between MY and PY on the other.

Table 4 shows the expected genetic increase in PY as a result of phenotype-based selection for MY or PP, or as a result of MAS directed at loci that affect exclusively PP or exclusively MY, or that affect both traits. All 5 studies show that expected gains from phenotypebased selection on PP are only a small fraction of those expected on the basis of selection on MY. This is primarily because $\mathrm{CV}_{\mathrm{MY}}$ averaged over the 5 studies is about 0.084 , whereas $\mathrm{CV}_{\mathrm{PP}}$ is about 0.042 . Thus, on average $\mathrm{k}=2.06$. When coupled with a negative genetic correlation of about -0.5 between $\mathrm{PP}$ and MY, this means that the indirect effect of selection for PP on PY, by way of the negative effect on MY of selection for PP, more or less cancels the direct effect of selection for PP on PY. In contrast, the indirect effect on PY of selection for MY, by way of the negative effect on PP of selection for MY, has much less effect than the direct effect on PY 
Table 3. Estimated (Est.) and observed (Obs.) values for phenotypic standard deviation $\left(\sigma_{\mathrm{PY}}\right)$ and heritability $\left(\mathrm{h}_{\mathrm{PY}}^{2}\right)$ of protein $(\mathrm{PY})$, and its genetic correlation with protein percentage $(\mathrm{PP})\left(\mathrm{r}_{\mathrm{A}(\mathrm{PP}, \mathrm{PY})}\right)$ and with milk yield (MY) $\left(\mathrm{r}_{\mathrm{A}(\mathrm{MY}, \mathrm{PY})}\right)$

\begin{tabular}{|c|c|c|c|c|c|c|c|c|}
\hline \multirow[b]{2}{*}{ Study } & \multicolumn{2}{|c|}{$\sigma_{\mathrm{PY}}$} & \multicolumn{2}{|c|}{$h_{P Y}^{2}$} & \multicolumn{2}{|c|}{$r_{A(P P, P Y)}$} & \multicolumn{2}{|c|}{$\mathrm{r}_{\mathrm{A}(\mathrm{MY}, \mathrm{PY})}$} \\
\hline & Obs. & Est. & Obs. & Est. & Obs. & Est. & Obs. & Est. \\
\hline Castillo-Juarez et al. (2002) & 60.5 & 60.4 & 0.25 & 0.25 & 0.05 & 0.06 & 0.88 & 0.87 \\
\hline Schutz et al. (1990) & 36.8 & 33.4 & 0.15 & 0.17 & 0.14 & 0.12 & 0.75 & 0.74 \\
\hline Sölkner (1989) & 18.0 & 18.0 & 0.27 & 0.27 & 0.03 & 0.03 & 0.79 & 0.87 \\
\hline Santus et al. (2003) & 29.0 & 29.4 & 0.31 & 0.30 & 0.03 & 0.03 & 0.92 & 0.92 \\
\hline Bagnato et al. (2008b) & 31.1 & 31.4 & 0.18 & 0.18 & -0.01 & 0.02 & 0.90 & 0.88 \\
\hline Mean & 35.1 & 34.5 & 0.23 & 0.23 & 0.05 & 0.05 & 0.85 & 0.86 \\
\hline
\end{tabular}

of selection for MY. Thus, selection for MY retains about $75 \%$ of its effect on PY, after taking its negative correlation with $\mathrm{PP}$ into account; but selection on PP retains only about $10 \%$ of its effect on PY, after taking its negative correlation with MY into account. With such a small expected effect on PY of a unit genetic change in PP, the genetic covariance between the 2 traits is necessarily small whereas the genetic variances of the traits are appreciable; hence, the very low genetic correlation of $\mathrm{PP}$ and PY.

Analysis of MAS shows that MAS directed at loci exclusively affecting MY have a strong positive effect on PY (mean $18.5 \mathrm{~kg}$ ), whereas the effect of loci exclusively affecting $\mathrm{PP}$ is about half this value (mean $9.5 \mathrm{~kg}$ ). Of great interest is the fact that MAS directed at loci affecting both MY and PP, if applied to the allele associated with positive effect on MY, will also have a positive effect on PY of similar magnitude to that provided by loci exclusively affecting PP (mean $9.3 \mathrm{~kg}$ ).

\section{DISCUSSION}

At the biometrical level, the results of this study show that the very large difference in genetic correlation between MY and PY compared with the genetic correlation of PP and PY can readily be explained by application to PY of the biometrical expressions derived by Essl (1978) for the genetic correlation of MY with fat percentage and fat yield. Basically, the difference is due to the fact that the genetic coefficient of variation of $\mathrm{PP}$ is only half that of MY. Thus, the effect on PY of a unit genetic change in PP is relatively small, and is more or less balanced by the accompanying opposite effect on PY generated by the negative genetic correlation between PP and MY. As a consequence, genetic variation in PP has very little net effect on PY. In contrast, a unit genetic change in MY has a large direct effect on PY, and this is countered only to a minor extent by the accompanying opposite effect on PY generated by

Table 4. Expected genetic increase in protein yield (PY) as a result of an increase of one additive genetic standard deviation in milk yield (MY) or protein percentage (PP) achieved by phenotype-based selection (Phen. Sel.) or marker-assisted selection (MAS) directed at loci that affect exclusively PP or exclusively MY $(\mathrm{PP}$ or $\mathrm{MY})$ or both traits $(\mathrm{PP}+\mathrm{MY})^{1}$

\begin{tabular}{|c|c|c|c|c|c|c|}
\hline \multirow[b]{2}{*}{ Study } & \multirow[b]{2}{*}{ Trait } & \multirow[b]{2}{*}{$\mathrm{k}$} & \multirow[b]{2}{*}{ PG } & \multirow{2}{*}{$\begin{array}{c}\text { Phen. } \\
\text { Sel. }^{2}\end{array}$} & \multicolumn{2}{|c|}{ MAS } \\
\hline & & & & & $\mathrm{PP}$ or MY & $\mathrm{PP}+\mathrm{MY}$ \\
\hline \multirow[t]{2}{*}{ Castillo-Juarez et al. (2002) } & MY & 2.05 & 0.072 & 26.51 & 33.53 & 17.20 \\
\hline & PP & & & 1.90 & 16.32 & -17.20 \\
\hline \multirow[t]{2}{*}{ Schutz et al. (1990) } & MY & 1.47 & 0.159 & 10.06 & 16.57 & 5.35 \\
\hline & PP & & & 1.60 & 12.21 & -5.35 \\
\hline \multirow[t]{2}{*}{ Sölkner (1989) } & MY & 2.06 & 0.033 & 8.15 & 10.50 & 5.39 \\
\hline & PP & & & 0.27 & 5.06 & -5.39 \\
\hline \multirow[t]{2}{*}{ Santus et al. (1993) } & MY & 2.57 & 0.036 & 14.8 & 17.18 & 10.5 \\
\hline & PP & & & 0.53 & 6.68 & -10.5 \\
\hline \multirow[t]{2}{*}{ Bagnato et al. (2008b) } & MY & 2.13 & 0.024 & 11.8 & 14.9 & 7.94 \\
\hline & PP & & & 0.28 & 7.01 & -7.94 \\
\hline \multirow[t]{2}{*}{ Mean } & MY & 2.15 & 0.065 & 14.3 & 18.5 & 9.28 \\
\hline & PP & & & 0.92 & 9.46 & -9.28 \\
\hline
\end{tabular}

${ }^{1} \mathrm{k}$ = relative magnitude of $\mathrm{CV}_{\mathrm{MY}}$ compared with $\mathrm{CV}_{\mathrm{PP}} ; \mathrm{PG}=$ proportional gain due to phenotype-based selection in PY due to increase of $1.0 \sigma_{\mathrm{APP}}$, compared with increase of $1.0 \sigma_{\mathrm{AMY}}$.

${ }^{2}$ For phenotypic selection, the observed genetic correlation of MY and PP for the particular study was used, whereas for MAS on loci affecting both traits the global genetic correlation of -0.5 [i.e., $\mathrm{r}_{\mathrm{A}(\mathrm{MY}, \mathrm{PP})^{\prime}}=$ $-1.0]$ was applied in all cases. 
the negative correlation between PP and MY. Thus, selection for MY will have a strong positive effect on $\mathrm{PY}$ and negative effect on PP, whereas selection for PP will have a strong negative effect on MY with a negligible effect on PY.

Mapping of QTL for MY and PP identified 3 classes of loci: those that exclusively affect PP, those that exclusively affect MY, and those that affect both traits. From the point of view of increasing PY, selection at loci that exclusively affect MY will have the most powerful effects, but will be accompanied by the deleterious effects of high milk production on functional traits (e.g., mastitis susceptibility, reproductive performance). Selection at loci that exclusively affect PP will have only about half of the effect of selection for those affecting MY, but will not be accompanied by deleterious functional effects. Finally, selection for alleles with a positive effect on MY at loci that affect both MY and PP will be quite effective in increasing PY, but this will also involve an increase in MY with associated deleterious effects on functional traits, together with a decrease in PP. Thus, the present analysis shows that selection at all loci affecting MY or PP or both will have effects on PY. However, the magnitude of effects on PY and the correlated effects on functional traits and milk composition will differ according to the primary effect of the locus. Thus, in contrast to our previous speculation (Bagnato et al., 2008a; Lipkin et al., 2008), loci affecting both MY and PP will not be neutral in their effect on PY. Rather, selection at these loci for the alleles that increase MY will increase PY, whereas selection for the alleles that increase PP will decrease PY.

A genetic correlation of about -1 between MY and PP for loci that affect both traits agrees well with the hypothesis formulated by Viitala et al. (2003) that loci affecting both MY and PP act by changing the volume of fluid milk through osmotic effects, presumably through changes in lactose concentration (Chamberlain et al., 2008). However, if only fluid volume is involved, a given proportional change in 1 unit of the traits must result in an exactly equivalent proportional change in the other trait. For example, if mean MY and $\mathrm{PP}=10,000 \mathrm{~kg}$ and $3.0 \%$, respectively, then an increase of $10 \%$ in MY (to $11,000 \mathrm{~kg}$ ), if due to fluid volume only, will result in a $10 \%$ decrease in PP (to $2.7 \%$ ). Therefore, if only a fluid volume relationship was involved, loci affecting both traits would cause an equivalent proportion change in each, and $\mathrm{CV}_{\mathrm{PP}}$ and $\mathrm{CV}_{\mathrm{MY}}$ would be the same. Thus, the larger CV of MY relative to PP remains to be explained.

In principle, the larger genetic CV of MY might be due to a larger number of loci that affects exclusively $\mathrm{MY}$ and a smaller number of such loci affecting PP, or to individual locus effects on $\mathrm{PP}$ being relatively smaller than individual locus effects on MY. Although Lipkin et al. (2008) indeed found a somewhat greater proportion of QTL affecting MY than PP (27.2 and $17.2 \%$, respectively), Bagnato et al. (2008b) found the opposite (18.6 and $23.2 \%$, respectively), contraindicating the first alternative. The second alternative is contraindicated by the fact that QTL mapping is more or less as effective in uncovering QTL affecting PP as QTL affecting MY; all else being equal, this would imply effects of similar magnitude for the loci affecting the 2 traits.

A possible solution is suggested by the greater heritability of PP compared with MY (Table 1). With a roughly equal number of loci affecting both traits and with the effects at each locus at most proportionately the same for PP and MY, the greater heritability of PP cannot be due to an overall greater genetic component of variance for PP. Hence, it must be due to a lower environmental component of variance. That is, we may speculate that PP is more tightly controlled against environmental variation than MY. Indeed, it seems physiologically plausible that it would be more difficult for the suckling calf to adjust milk intake to compensate for large short-term fluctuations in milk composition than for the cow to control milk composition. The same buffering mechanism could act to reduce genetic variation in milk composition as well. Thus, on the assumption of strong buffering against environmental and genetic variation in $\mathrm{PP}$, it is possible to have small absolute effects at the individual locus, yet high power to uncover the locus by linkage mapping.

The results of this analysis are consistent with the effects on MY and PP that have accompanied the increase in protein yield reported for most Holstein and Brown Swiss populations over the past decades (see, for example, the summary of trends for the US Holstein and Brown Swiss: http://aipl.arsusda.gov/eval/summary/trend.cfm; summary of trend in Italian Brown Swiss http://www.anarb.it). In all cases, increase in PY has been accompanied by large increase in MY. The effect on PP has varied, however, depending on the weight allocated to PP in the national selection index: drifting lower in the US Holstein population (see Summary of Trends Web site), but increasing in the Italian Brown Swiss (http://www.anarb.it) and Israel Holstein populations (E. Ezra, Israel Cattle Breeders Association, Caesaria, Israel; personal communication). This variation in $\mathrm{PP}$ response is easily accommodated if there are loci that are free to respond to selection for $\mathrm{PP}$, without negative effects on MY and with positive effects on PY.

The specific case discussed in this study could be used as a basis for investigating other traits that present similar negative genetic correlation (such as MY and female fertility, or egg number and egg weight) and 
where selection can be on the basis of global EBV, whether based on phenotype, or on genome-wide scans such as those proposed by Meuwissen et al. (2001), or on the basis of individual known loci that differ in their effects on the 2 traits.

\section{ACKNOWLEDGMENT}

This research was supported by the FP5 program of the EU (BovMAS project QLK5-CT-2001-02379). The authors thank Alois Essl for his helpful comments, Johann Söelkner and Peter Vischer for drawing our attention to relevant literature, and one of the referees for drawing our attention to the more general implications of this study.

\section{REFERENCES}

Bagnato, A., A. B. Samoré, C. Romani, A. Rossoni, S. Ghiroldi, and R. Rizzi. 2008b. Variance Components Estimation in the Italian Brown Breed. http://www.anarb.it/ricerca_valgen/studi_ricerche/ 2008/2008_variance.pdf. Accessed Mar. 19, 2008.

Bagnato, A., F. Schiavini, A. Rossoni, C. Maltecca, M. Dolezal, I. Medugorac, J. Sölkner, V. Russo, L. Fontanesi, A. Friedmann, M. Soller, and E. Lipkin. 2008a. Quantitative trait loci affecting milk yield and protein percentage in a three-country Brown Swiss population. J. Dairy Sci. 91:767-783.

Castillo-Juarez, H., P. A. Oltenacu, and E. G. Cienfuegos-Rivas. 2002. Genetic and phenotypic relationships among milk production and composition traits in primiparous Holstein cows in two different herd environments. Livest. Prod. Sci. 78:223-231.

Chamberlain, A. J., H. C. McPartlan, and M. E. Goddard. 2008. Genes influencing milk production traits predominantly affect one of four biological pathways. Genet. Sel. Evol. 40:79-89.
Chauhan, V. P., and J. F. Hayes. 1991. Genetic parameters for first milk production and composition traits for Holsteins using multivariate restricted maximum likelihood. J. Dairy Sci. 74:603-610.

Essl, A. 1978. Biometric relations between some population parameters for milk yield, fat contents, fat yield and fat-corrected milk yield. Z. Tierzucht. Zuchtungsbiol. 95:204-210.

Lipkin, E., R. Tal, A. Friedmann, and M. Soller. 2008. Effect of quantitative trait loci for milk protein percent on milk protein yield and milk yield in Israel Holstein dairy cattle. J. Dairy Sci. 91:1614-1627.

Meuwissen, T. H. E., B. J. Hayes, and M. E. Goddard. 2001. Prediction of total genetic value using genome-wide dense marker map. Genetics 157:1819-1829.

Ron, M., E. Feldmesser, M. Golik, I. Tager-Cohen, D. Kliger, V. Reiss, R. Domochovsky, O. Alus, E. Seroussi, E. Ezra, and J. I. Weller. 2004. A complete genome scan of the Israeli Holstein population for quantitative trait loci by a daughter design. J. Dairy Sci. 87:476-490.

Santus, E. C., R. W. Everett, R. L. Quaas, and D. M. Galton. 1993. Genetic parameter estimation of Italian Brown Swiss for level of herd yield. J. Dairy Sci. 76:3594-3600.

Schutz, M. M., L. B. Hansen, G. R. Steuernagel, J. K. Reneau, and A. L. Kuck. 1990. Genetic parameters for somatic cells, protein and fat in milk of Holsteins. J. Dairy Sci. 73:494-502.

Sölkner, J. 1989. Genetic relationships between level of production in different lactations, rate of maturity and longevity in a dual purpose cattle population. Livest. Prod. Sci. 23:33-45.

Viitala, S. M., N. F. Schulman, D. J. de Koning, K. Elo, R. Kinos, A. Virta, J. Virta, A. Mäki-Tanila, and J. H. Vilkki. 2003. Quantitative trait loci affecting milk production traits in Finnish Ayrshire dairy cattle. J. Dairy Sci. 86:1828-1836.

Visscher, P. M., and T. Thompson. 1992. Univariate and multivariate parameter estimates for milk production traits using an animal model. I. Description and results of REML analysis. Genet. Sel. Evol. 24:415-430.

Welper, R. D., and A. E. Freeman. 1992. Genetic parameters for yield traits of Holsteins, including lactose and somatic cell score. J. Dairy Sci. 75:1342-1348. 